\title{
Effect of Colour Plastic Mulching on Plant Growth Parameters of Okra (Abelmoschus esculentus) Crop under Different Levels of Drip Irrigation
}

\author{
S. Shivaraj ${ }^{1 *}$, P. Balakrishnan ${ }^{1}$, G.V. Srinivas Reddy ${ }^{1}$, Kavita Kandpal ${ }^{2}$ and R.P. Patil $^{3}$ \\ ${ }^{1}$ Department of Soil and Water Engineering, UAS, Raichur, Karnataka, India \\ ${ }^{2}$ Department of Harticulture, UAS, Raichur, Karnataka, India \\ ${ }^{3}$ Department of Crop physiology, UAS, Raichur, Karnataka, India
}

*Corresponding author

\section{A B S T R A C T}

\section{Keywords \\ Colour plastic mulch, Okra, Drip irrigation \\ Article Info \\ Accepted: \\ 28 January 2018 \\ Available Online: \\ 10 February 2018}

\begin{abstract}
An experiment was conducted on the effect of colour plastic mulches on plant height, days to fifty per cent flowering, leaf area index under different irrigation levels. The treatments were laid out in split plot design with three replications and a non-mulched treatment as control. The plastic coloured mulches used were white on black, silver on black and black. The irrigation levels used were 60, 80,100 and 120 per cent ET. The results indicated that the growth components of plant height, days to fifty per cent flowering and leaf area index were significantly influenced by drip irrigation levels. The maximum plant height (210 $\mathrm{cm}$ ), least days to 50 per cent flowering (42 days), highest leaf area index (3.60) and highest chlorophyll were recorded under drip irrigation at 80 per cent ET with white on black plastic colour mulch when compared to other treatments throughout the growing period.
\end{abstract}

\section{Introduction}

Okra is the only vegetable crop of significance in the Malvaceae family and is very popular in the Indo-Pak subcontinent. It is one of the oldest cultivated crops and presently cultivated throughout the tropical, subtropical and warm temperate regions of the world for its fibrous fruits or pods containing round white seeds.

Plastic mulch was first noted for its ability to increase soil temperature in the 1950s. It is beneficial to adjust the soil microclimate to prolong the growing season and increase plant growth (Tarara, 2000). A variety of colour mulches has been used by growers and researchers in vegetable production. White plastic mulch has been shown to generate cooler soil temperatures than black plastic (Diaz-Perez and Batal, 2002). Therefore, the use of white plastic mulch is preferred during the summer growing season in warmer climates globally compared to black plastic. Silver plastic mulch has resulted in less disease incidence. The use of red plastic mulch has been found to result in higher yields in tomato and to generate a positive phytochrome compared to the use of black plastic or no plastic. Beneficial aspects of plastic mulch include conservation of moisture, weed control and maintaining 
moderate soil temperature for better root growth and higher crop yield.

Drip irrigation was practised all over the world towards the later part of the last century. This system has gained wide popularity in areas of acute water scarcity and in areas where horticultural and commercial crops are grown. Drip irrigation can help to use water efficiently.

Okra is one of the important vegetables most consumed in this part. As the studies on the effect of colour mulching on horticultural crops were not undertaken in this region, such studies would provide much needed information for boosting their productivity and production. Thus, the results of the present project on the test crop okra would lead to the outcome of providing the appropriate technological information on the effect of colour mulching in combination with drip irrigation, which would give quality and maximum okra yield.

\section{Materials and Methods}

A field experiment was undertaken to observe the effect of different colour plastic mulches on the growth and yield of okra (MAHY 28, hybrid) against without mulch. This experiment was conducted at UAS-Raichur, which is situated in Karnataka of India. The highest maximum temperature of $33.4^{\circ} \mathrm{C}$ was recorded in the month of October, 2015 and lowest temperature of $14.0^{\circ} \mathrm{C}$ was recorded in the month of December, 2015. The Treatments were tested in split plot design with three replications. Each replication has 16 beds. The main treatments were $\mathrm{I}_{1^{-}}$-Water application at 60 per cent ET using drip irrigation, $\mathrm{I}_{2}$ - Water application at 80 per cent ET using drip irrigation, $\mathrm{I}_{3}-$ Water application at 100 per cent ET using drip irrigation and $\mathrm{I}_{4^{-}}$Water application at 120 per cent ET using drip irrigation and sub treatments were $\mathrm{M}_{0}-$
Without mulch (control), $\mathrm{M}_{1}-$ White on black plastic mulch, $\mathrm{M}_{2}-$ Silver on black plastic mulch and $\mathrm{M}_{3}-$ Black plastic mulch.

The experimental plots of $5 \mathrm{~m} \times 1 \mathrm{~m}$ were prepared for sowing of okra seeds. The plant to plant and row to row spacing were 0.30 and $0.45 \mathrm{~m}$ respectively. The different plastic colour mulches of 30-micron thickness are white on black, silver on black and black was cut as per the size of the plots. The data was recorded at intervals of $30,45,60,75$ and 90 days after sowing (DAS).The observations were recorded on five randomly selected plants in each plot.

Data were recorded on plant height, days to fifty per cent flowering, leaf area index. Plant height was measured in $\mathrm{cm}$ from the base of the plant to the top of the plant with the help of metre scale. Number of days taken from the DAS to the initiation of flowering in fifty per cent of the total plants in entire plot was considered as days to fifty per cent flowering and expressed in days. The leaf area index (LAI) was measured with an AccuPAR 80 Ceptometer (Decagon Devices, Inc., Pullman, WA, USA) between 11:30 am and 3:30 pm.

\section{Results and Discussion}

\section{Plant height}

The effect of irrigation levels, mulch colours and their interactions on plant height recorded in different dates i.e. 30, 45, 60, 75 and 90 DAS are presented in Table 1(a) and 1(b). Among the irrigation levels, drip irrigation at 80 per cent ET $(195.25 \mathrm{~cm})$ resulted in significantly taller plants followed by drip irrigation at 100 per cent ET $(184.17 \mathrm{~cm})$ and 60 per cent ET $(182.00 \mathrm{~cm})$. The plant height was markedly lower in case of drip irrigation at 120 per cent ET $(173.08 \mathrm{~cm})$. Significantly tallest plants were observed with white on black plastic mulch $(198.00 \mathrm{~cm})$ followed by 
silver on black plastic mulch $(192.75 \mathrm{~cm})$ and black plastic mulch $(184.00 \mathrm{~cm})$ at all the intervals in different DAS. Smaller plants were recorded under the control (no mulch) treatment $(159.75 \mathrm{~cm})$.

In combination of treatment, the maximum plant height $(210 \mathrm{~cm})$ were recorded under drip irrigation at 80 per cent ET with white on black plastic colour mulch when compared to other treatments throughout the growing period. Positive influence of white on black plastic mulch on plant height might be due to the fact that the incident radiation entered through the white polythene mulch, but very little amount of outgoing radiation could go back to the environments, which slightly improved the soil temperature underneath the white mulch. Similar trend was also reported by Kumar et al., (2010).

\section{Days to fifty per cent flowering}

The effect of irrigation levels and coloured mulches and their interaction on number of day to 50per cent flowering are presented in Table 3 and shown in Figure 1. Drip irrigation at 80 per cent ET (43.33 days) was more effective to induce early flowering as compared to drip irrigation at 120 per cent ET (44.17 days). In combination of treatment, minimum days to fifty per cent flowering (42 days) were recorded under drip irrigation at 80 per cent ET with white on black plastic colour mulch when compared to other treatments throughout the growing period. Among mulch colours, white on black plastic mulch was effective for earliness in 50 per cent flowering as compared to control. The results were in agreement with the findings of Chakraborty et al., (1994) and Hooda et al., (1998).

\section{Leaf area index (LAI)}

The effect of irrigation levels, mulch colours and their interactions on leaf area index recorded) in different dates i.e. 30, 45, 60, 75 and 90 DAS are presented in Table 2(a) and 2(b). The Table showed that the leaf area index values recorded at 30, 45, 60, 75 and 90 DAS were significantly influenced by irrigation levels and mulch colours. Among the irrigation level LAI was more in $\mathrm{I}_{2}(0.44$, $0.99,1.54,2.38$ and 3.33 respectively) followed by $\mathrm{I}_{3}, \mathrm{I}_{4}$ and $\mathrm{I}_{1}$. The LAI recorded higher in mulched plot as compared to plot without mulch. The LAI was more in $\mathrm{M}_{1}(0.35,0.99$ $1.59,2.43$ and 3.40) followed by $\mathrm{M}_{2}, \mathrm{M}_{3}$ and $\mathrm{M}_{0}$ at 30, 45, 60, 75 and 90 DAS respectively. The leaf area index ranged from (0.40to 0.39), (1.06 to 0.74$),(1.60$ to 1.12$),(2.43$ to 1.67$)$ and (3.60 to 2.70) under the treatments $\mathrm{I}_{2} \mathrm{M}_{1}$ and $\mathrm{I}_{1} \mathrm{M}_{0}$ due to the interaction effect at 30, 45, 60, 75 and 90 DAS respectively. The LAI increased from emergence and reached its peak at crop maturity. These results were in line and agreement with the findings by Konyeha et al., (2013).

\section{Chlorophyll - a and Chlorophyll - b}

The effect of irrigation levels, mulch colours and their interactions on Chlorophyll - a and Chlorophyll - $\mathrm{b}$ recorded in different dates i.e. 30 and 60 DAS are depicted through Figure 2 and 3 .

The Chlorophyll - a and Chlorophyll - b were higher in 80 per cent ET through drip irrigation at 30 and 60 DAS and The Chlorophyll - a Chlorophyll - b were more in white on black plastic colour mulch followed by silver on black plastic colour mulch and black plastic colour mulch as compared with control bed. Chlorophyll - a and Chlorophyll $b$ could be due to the spectral distribution of light reflected from the colour of the mulch and the reason might be due to the differences in the quality and quantity of light transmitted absorbed and reflected from the colour of the mulch which in turn might affect the plant growth and development including its quality. 
Table.1 (a) Effect of different levels of irrigation and plastic mulch colours on plant height, $\mathrm{cm}$

\begin{tabular}{|c|c|c|c|c|c|c|c|c|c|c|c|c|c|c|c|}
\hline \multirow[t]{2}{*}{ Treatment } & & & 30 DAS & & & & & 45 DAS & & & & & 60 DAS & & \\
\hline & $\mathbf{I}_{1}$ & $\mathbf{I}_{2}$ & $\mathbf{I}_{3}$ & $\mathbf{I}_{4}$ & Mean & $\mathbf{I}_{1}$ & $\mathbf{I}_{2}$ & $\mathbf{I}_{3}$ & $\mathbf{I}_{4}$ & Mean & $\mathbf{I}_{1}$ & $\mathbf{I}_{2}$ & $\mathbf{I}_{3}$ & $\mathbf{I}_{4}$ & Mean \\
\hline $\mathbf{M}_{0}$ & 18.67 & 31.33 & 28.00 & 30.00 & 27.00 & 62.00 & 69.33 & 65.00 & 64.33 & 65.17 & 88.33 & 116.00 & 92.00 & 83.00 & 94.83 \\
\hline $\mathbf{M}_{1}$ & 31.67 & 32.33 & 32.33 & 30.00 & 31.58 & 92.33 & 93.33 & 89.00 & 83.00 & 89.42 & 134.33 & 144.00 & 144.00 & 133.67 & 139.00 \\
\hline $\mathbf{M}_{2}$ & 30.67 & 35.00 & 34.00 & 31.00 & 32.67 & 91.67 & 91.67 & 73.33 & 74.00 & 82.67 & 137.67 & 144.33 & 114.67 & 110.67 & 126.83 \\
\hline$\overline{\mathbf{M}_{3}}$ & 29.00 & 31.33 & 31.67 & 29.67 & 30.42 & 70.33 & 76.00 & 61.67 & 70.33 & 69.58 & 109.00 & 124.67 & 90.00 & 110.00 & 108.42 \\
\hline \multirow[t]{2}{*}{ Mean } & 27.50 & 32.50 & 31.50 & 30.17 & & 79.08 & 82.58 & 72.25 & 72.92 & & 117.33 & 132.25 & 110.17 & 109.33 & \\
\hline & & \multicolumn{2}{|c|}{$\mathrm{SEM} \pm$} & \multicolumn{2}{|c|}{$\mathrm{CD}$ at 5 per cent } & & \multicolumn{2}{|l|}{$\mathrm{SEM} \pm$} & \multicolumn{2}{|c|}{$\mathrm{CD}$ at 5 per cent } & & \multicolumn{2}{|l|}{$\mathrm{SEM} \pm$} & \multicolumn{2}{|c|}{$\mathrm{CD}$ at 5 per cent } \\
\hline \multicolumn{2}{|c|}{ Main treatment } & \multicolumn{2}{|c|}{0.98} & \multicolumn{2}{|c|}{3.40} & & \multicolumn{2}{|l|}{1.95} & \multicolumn{2}{|c|}{6.74} & & \multicolumn{2}{|l|}{4.85} & \multicolumn{2}{|c|}{16.79} \\
\hline \multicolumn{2}{|c|}{ Sub treatment } & \multicolumn{2}{|c|}{1.22} & \multicolumn{2}{|c|}{3.56} & & \multicolumn{2}{|l|}{3.48} & \multicolumn{2}{|c|}{10.17} & & \multicolumn{2}{|l|}{4.42} & \multicolumn{2}{|c|}{12.89} \\
\hline \multicolumn{2}{|c|}{ I at same $\mathrm{M}$} & \multicolumn{2}{|c|}{2.43} & \multicolumn{2}{|c|}{ NS } & & \multicolumn{2}{|l|}{$\begin{array}{l}6.97 \\
6.34\end{array}$} & \multicolumn{2}{|c|}{ NS } & & \multicolumn{2}{|l|}{8.83} & \multicolumn{2}{|c|}{ NS } \\
\hline \multicolumn{2}{|c|}{ M at same or different I } & \multicolumn{2}{|c|}{2.32} & \multicolumn{2}{|c|}{ NS } & & \multicolumn{2}{|l|}{6.34} & \multicolumn{2}{|c|}{ NS } & & \multicolumn{2}{|l|}{9.06} & & \\
\hline
\end{tabular}

\section{Main treatments:}

$\mathrm{I}_{1}$ : Drip irrigation at $60 \% \mathrm{ET}$

$\mathrm{I}_{2}$ : Drip irrigation at $80 \% \mathrm{ET}$

$\mathrm{I}_{3}$ : Drip irrigation at $100 \% \mathrm{ET}$

$\mathrm{I}_{4}$ : Drip irrigation at $120 \% \mathrm{ET}$

\section{Sub treatments:}

$\mathrm{M}_{0:}$ Without mulch condition

$\mathrm{M}_{1}$ : White on black plastic mulch

$\mathrm{M}_{2}$ : Silver on black plastic mulch

$\mathrm{M}_{3}$ : Black plastic colour mulch

Table.1 (b) Effect of different levels of irrigation and plastic mulch colours on plant height, cm

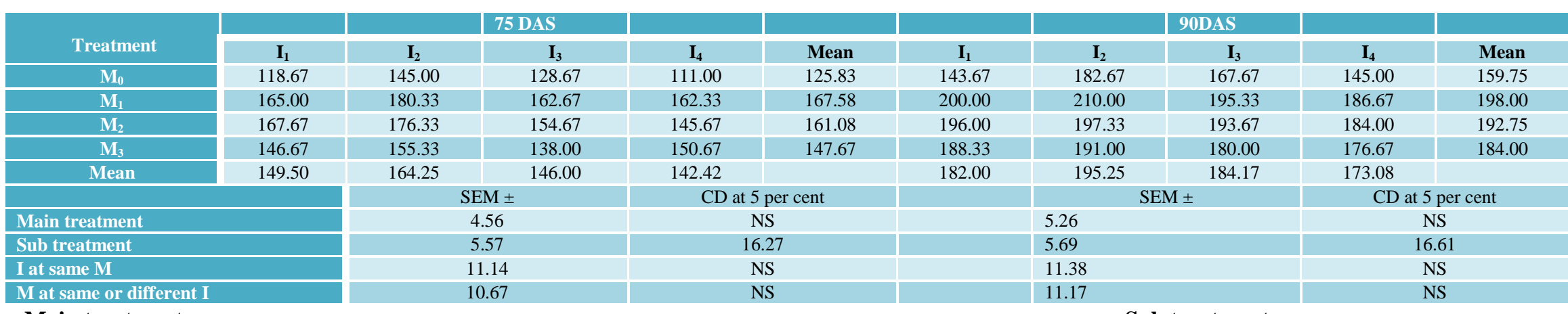

\section{Main treatments}

$\mathrm{I}_{1}$ : Drip irrigation at $60 \% \mathrm{ET}$

$\mathrm{I}_{2}$ : Drip irrigation at $80 \% \mathrm{ET}$

$\mathrm{I}_{3}$ : Drip irrigation at $100 \% \mathrm{ET}$

$\mathrm{I}_{4}$ : Drip irrigation at $120 \% \mathrm{ET}$

\section{Sub treatments:}

$\mathrm{M}_{0 \text { : Without mulch condition }}$

$\mathrm{M}_{1}$ : White on black plastic mulch

$\mathrm{M}_{2}$ : Silver on black plastic mulch

$\mathrm{M}_{3}$ : Black plastic colour mulch 
Table.2 (a) Effect of different levels of irrigation and plastic mulch colours on leaf area index

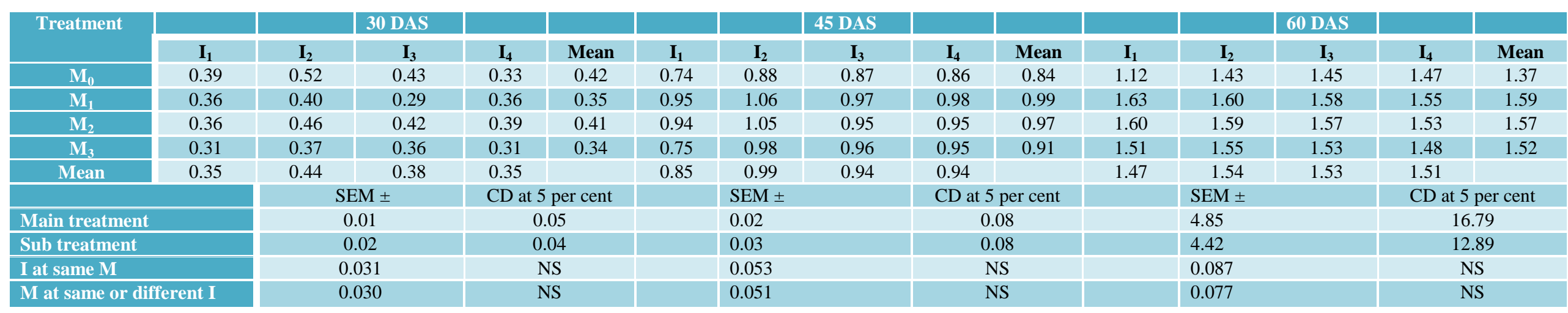

\section{Main treatments:}

$\mathrm{I}_{1}$ : Drip irrigation at $60 \% \mathrm{ET}$

$\mathrm{I}_{2}$ : Drip irrigation at $80 \% \mathrm{ET}$

$\mathrm{I}_{3}$ : Drip irrigation at $100 \% \mathrm{ET}$

$\mathrm{I}_{4}$ : Drip irrigation at $120 \% \mathrm{ET}$

\section{Sub treatments:}

$\mathrm{M}_{0 \text { : Without mulch condition }}$

$\mathrm{M}_{1}$ : White on black plastic mulch

$\mathrm{M}_{2}$ : Silver on black plastic mulch

$\mathrm{M}_{3}$ : Black plastic colour mulch

Table.2 (b) Effect of different levels of irrigation and plastic mulch colours on leaf area index

\begin{tabular}{|c|c|}
\hline \multicolumn{1}{|c|}{ Treatment } & \\
\hline & $\mathbf{I}_{\mathbf{1}}$ \\
\hline $\mathrm{M}_{0}$ & 1.67 \\
\hline $\mathrm{M}_{1}$ & 2.45 \\
\hline $\mathrm{M}_{2}$ & 2.42 \\
\hline $\mathrm{M}_{3}$ & 2.40 \\
\hline \multicolumn{2}{|c|}{ Mean } \\
\hline \multicolumn{2}{|c|}{2.23} \\
\hline Main treatment \\
\hline Sub treatment \\
\hline I at same M \\
\hline M at same or different I \\
\hline
\end{tabular}

\section{Main treatments}

$\mathrm{I}_{1}$ : Drip irrigation at $60 \% \mathrm{ET}$

$\mathrm{I}_{2}$ : Drip irrigation at $80 \% \mathrm{ET}$

$\mathrm{I}_{3}$ : Drip irrigation at $100 \% \mathrm{ET}$

$\mathrm{I}_{4}$ : Drip irrigation at $120 \% \mathrm{ET}$

\begin{tabular}{|c|c|c|c|c|c|c|c|c|}
\hline & 75 DAS & & & & & 90DAS & & \\
\hline $\mathbf{I}_{2}$ & $\mathbf{I}_{3}$ & $\mathbf{I}_{4}$ & Mean & $\mathbf{I}_{1}$ & $\mathbf{I}_{2}$ & $\mathbf{I}_{3}$ & $\mathbf{I}_{4}$ & Mean \\
\hline 2.30 & 2.20 & 2.23 & 2.10 & 2.70 & 3.00 & 3.13 & 3.14 & 2.99 \\
\hline 2.43 & 2.42 & 2.41 & 2.43 & 3.45 & 3.60 & 3.32 & 3.23 & 3.40 \\
\hline 2.40 & 2.40 & 2.37 & 2.40 & 3.34 & 3.41 & 3.29 & 3.16 & 3.30 \\
\hline 2.40 & 2.40 & 2.33 & 2.38 & 3.22 & 3.30 & 3.27 & 3.03 & 3.21 \\
\hline 2.38 & 2.35 & 2.34 & & 3.18 & 3.33 & 3.25 & 3.14 & \\
\hline \multicolumn{2}{|c|}{$\mathrm{SEM} \pm$} & \multicolumn{2}{|c|}{$\mathrm{CD}$ at 5 per cent } & & \multicolumn{2}{|l|}{$\mathrm{SEM} \pm$} & \multicolumn{2}{|c|}{$\mathrm{CD}$ at 5 per cent } \\
\hline \multicolumn{2}{|c|}{0.02} & \multicolumn{2}{|c|}{0.09} & & \multicolumn{2}{|l|}{0.03} & \multicolumn{2}{|c|}{0.11} \\
\hline \multicolumn{2}{|c|}{0.04} & \multicolumn{2}{|c|}{0.13} & & \multicolumn{2}{|l|}{0.05} & \multicolumn{2}{|c|}{0.14} \\
\hline \multicolumn{2}{|c|}{0.08} & \multicolumn{2}{|c|}{0.25} & & \multicolumn{2}{|l|}{0.09} & \multicolumn{2}{|c|}{0.27} \\
\hline \multicolumn{2}{|c|}{0.08} & \multicolumn{2}{|c|}{0.23} & & \multicolumn{2}{|l|}{0.08} & \multicolumn{2}{|c|}{0.25} \\
\hline
\end{tabular}

\section{Sub treatments:}

$\mathrm{M}_{0 \text { : Without mulch condition }}$

$\mathrm{M}_{1}$ : White on black plastic mulch

$\mathrm{M}_{2}$ : Silver on black plastic mulch

$\mathrm{M}_{3}$ : Black plastic colour mulch 
Table.3 Effect of different levels of irrigation and plastic mulch colours on number of days to fifty per cent flowering

\begin{tabular}{|c|c|c|c|c|c|}
\hline Treatment & $\mathbf{I}_{1}$ & $\mathbf{I}_{2}$ & $\mathbf{I}_{3}$ & $\mathbf{I}_{4}$ & Mean \\
\hline $\mathbf{M}_{0}$ & 45.33 & 44.33 & 45.00 & 45.67 & 45.08 \\
\hline $\mathbf{M}_{1}$ & 42.67 & 42.00 & 43.33 & 43.00 & 43.75 \\
\hline $\mathbf{M}_{2}$ & 43.00 & 43.00 & 43.67 & 43.33 & 43.25 \\
\hline $\mathbf{M}_{3}$ & 44.00 & 44.00 & 44.00 & 44.67 & 44.17 \\
\hline Mean & 43.75 & 43.33 & 44.00 & 44.17 & \\
\hline & & \multicolumn{2}{|c|}{$\mathrm{SEM} \pm$} & \multicolumn{2}{|c|}{$\mathrm{CD}$ at 5 per cent } \\
\hline Main treatment & & \multicolumn{2}{|c|}{0.11} & \multicolumn{2}{|c|}{0.37} \\
\hline Sub treatment & & \multicolumn{2}{|c|}{0.13} & \multicolumn{2}{|c|}{0.38} \\
\hline I at same $\mathbf{M}$ & & \multicolumn{2}{|c|}{0.26} & \multicolumn{2}{|c|}{ NS } \\
\hline \multicolumn{2}{|c|}{ M at same or different I } & \multicolumn{2}{|c|}{0.25} & \multicolumn{2}{|c|}{ NS } \\
\hline
\end{tabular}

Fig.1 Effect of different levels of irrigation and plastic mulch colours on number of days to fifty per cent flowering

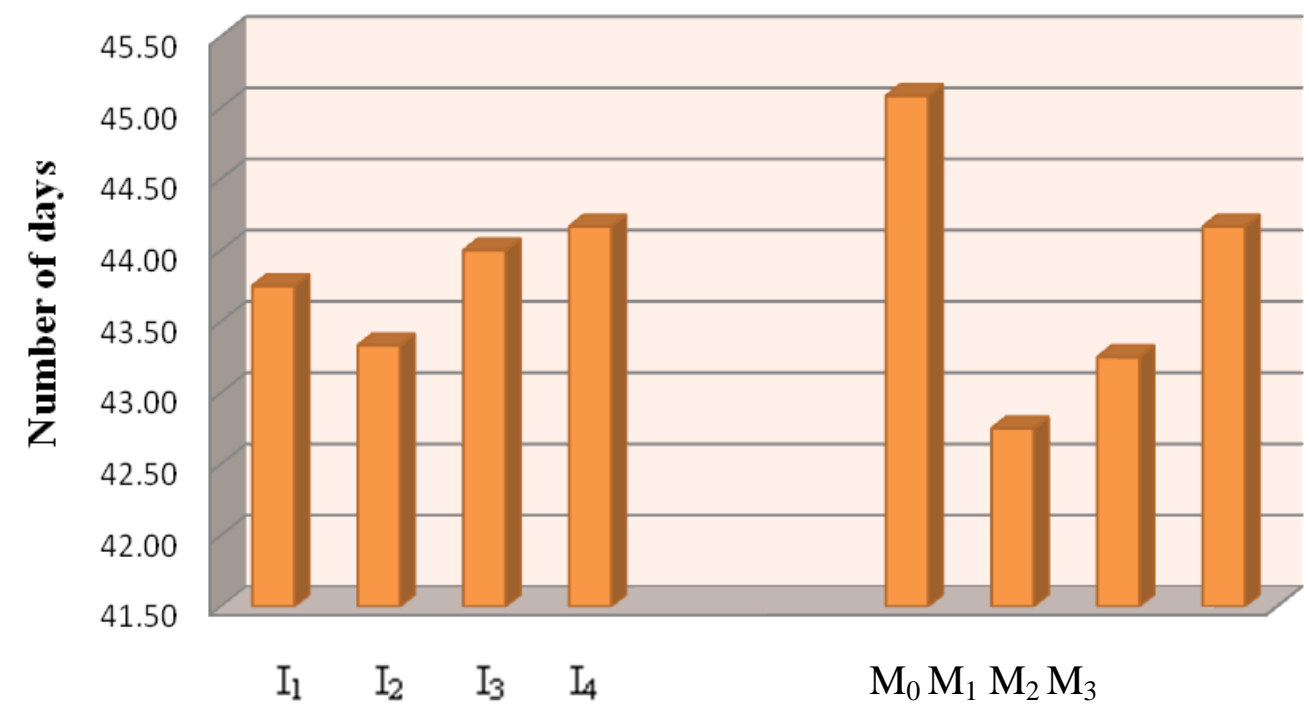

Irrigation level

Mulch colour 
Fig.2 Effect of different levels of irrigation and mulch colours on chlorophyll - a and chlorophyll - b (30 Days after sowing)

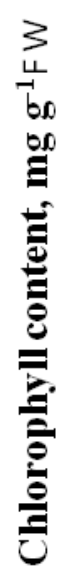

$\square \mathrm{chla}$

$\square \mathrm{chlb}$

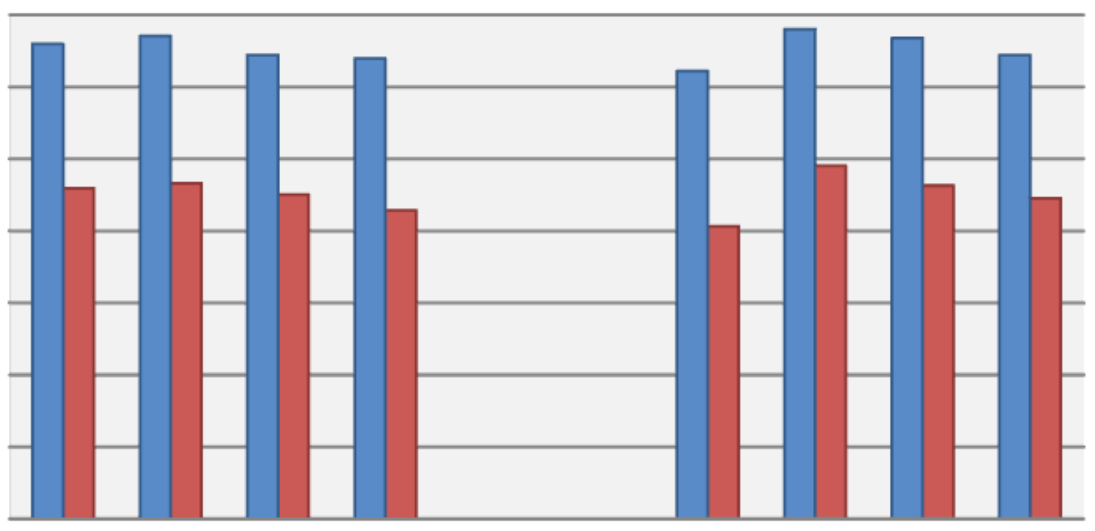

$\begin{array}{llll}\mathrm{I}_{1} & \mathrm{I}_{2} & \mathrm{I}_{3} & \mathrm{I}_{4}\end{array}$

Irrigation level
$\mathrm{M}_{0} \mathrm{M}_{1} \mathrm{M}_{2} \mathrm{M}_{3}$

Mulch colour

Fig.3 Effect of different levels of irrigation and mulch colours on chlorophyll - a and chlorophyll - b (60 Days after sowing)

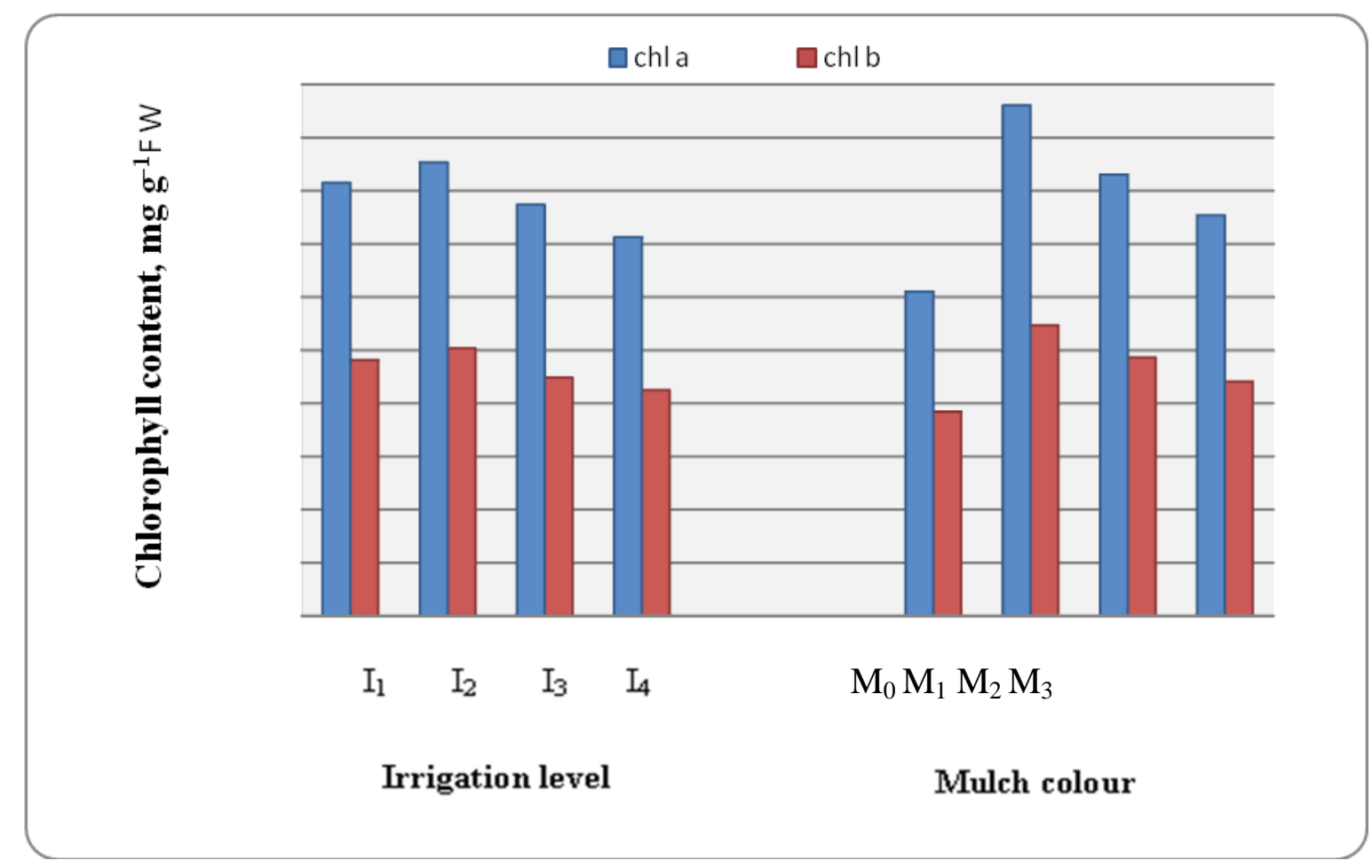


The above results are in agreement with findings of Franquera (2015).

The study concluded that the drip irrigation at 80 per cent ET with white on black plastic mulch enhanced better plant growth, which facilitated in accumulation of more photosynthates and conservation of optimum temperature resulting in increased size and weight of fruits. The maximum plant height $(210 \mathrm{~cm})$, least days to 50 per cent flowering (42 days), highest leaf area index (3.60) and higher chlorophylls were recorded under drip irrigation at 80 per cent ET with white on black plastic colour mulch when compared to other treatments throughout the growing period.

\section{References}

Chakraborty, R. C. and Sadhu, M. K., 1994, Effect of mulch type and colour on growth and yield of tomato. Indian $J$. Agric. Sci., 64 (9): 608-612.

Diaz Perez, J. C. and Batal, K. D., 2002, Coloured plastic film mulches affect tomato growth and yield via changes in root-zone temperature. J. American Soc., 127 (1): 127-136.

Franquera, E.N., 2015, Effects of Plastic Mulch Colour on the Total Soluble Solids, Total Sugars and Chlorophyll Content of Lettuce (Lactuca sativa L.), Int. J. Res. Agric. For., 2(8):18-24.

Hooda, S., Singh. R., Jitendra., Malik, Y. S., Narwal. A. K., 1998, Effect of seeding/planting time and mulching on tomato production. Horti. Sci., 27 (3): 195-200.

Konyeha, S. and Alatise, M. O., 2013, Evapotranspiration and leaf area index (LAI) of irrigated okra (Abelmoschus esculentus L. Moench) in Akure, SouthWestern City of Nigeria. Int. J. Engg. Res. Technol., 2 (9): 2880-2888.

Kumar, S., Chakraborty, B. and Singh, N., 2010, Effect of different mulching materials in rose cv.laher. $J$. Ornamental Horti., 13 (2): 95-100.

Tarara, J. M., 2000, Microclimate modifications with plastic mulch. Hortscience, 35 (2): 169-180.

\section{How to cite this article:}

Shivaraj, S., P. Balakrishnan, G.V. Srinivas Reddy, Kavita Kandpal and Patil, R.P. 2018. Effect of Colour Plastic Mulching on Plant Growth Parameters of Okra (Abelmoschus esculentus) Crop under Different Levels of Drip Irrigation. Int.J.Curr.Microbiol.App.Sci. 7(02): 34403447. doi: https://doi.org/10.20546/ijcmas.2018.702.410 